\title{
Redescription of Acanthocyclops vernalis (Fischer, 1853) and Acanthocyclops robustus (Sars, 1863) from neotypes, with special reference to their distinction from Acanthocyclops americanus (Marsh, 1892) and its invasion of Eurasia
}

\author{
Victor R. Alekseev1, ${ }^{1,}$, Maria R. Miracle2,†, Maria Sahuquillo²,3 and Eduardo Vicente ${ }^{2}$ \\ ${ }^{1}$ Zoological Institute of the Russian Academy of Sciences, Universitetskaya Embankment 1, St Petersburg \\ 199034, Russia. \\ 2 Department of Microbiology and Ecology, ICBiBE, University of Valencia, 46100 Burjassot, Valencia, \\ Spain. \\ 3 Subdirecció General del Medi Natural, Generalitat Valenciana, València, Spain. \\ $\dagger$ Deceased \\ * Corresponding author: alekseev@zin.ru
}

Received: 02/04/19 Accepted: 08/01/20

\begin{abstract}
Redescription of Acanthocyclops vernalis (Fischer, 1853) and Acanthocyclops robustus (Sars, 1863) from neotypes, with special reference to their distinction from Acanthocyclops americanus (Marsh, 1892) and its invasion of Eurasia

This paper provides a redescription of Acanthocyclops vernalis and A. robustus neotypes collected in their type localities in Russia (Orlov pond, Peterhof) and Norway (a stream outcoming from a lake in Oslo) with a special attention to their morphological differentiation from A. americanus. Due to overmixing of these species throughout most of the last century and fast arrival and spreading of the aggressive planktonic predator A. americanus, all previous indications of A. robustus should be checked and confirmed. More than 200 localities in Valencia region (Spain) and more than 30 localities in Armenia, Belgium, Egypt, Finland, France, Kazakhstan, Norway, Russia, Sweden and Tunisia were checked for the presence of A. americanus. In all these countries the invader was found in large numbers as dominant species often substituting other native Acanthocyclops species in limnetic communities. A brief history and possible explanation of the successful invasion of A. americanus in Eurasia is discussed.
\end{abstract}

Key words: Acanthocyclops robustus; Acanthocyclops vernalis; Acanthocyclops redescriptions; cyclopoid taxonomy; Acanthocyclops americanus; biological invasion, distribution in Eurasia

\section{RESUMEN}

Redescripción de los neotipos de Acanthocyclops vernalis (Fischer, 1853) y Acanthocyclops robustus (Sars, 1863), con especial atención a sus diferencias morfológicas con Acanthocyclops americanus (Marsh, 1892) y su invasión en Eurasia

Este trabajo proporciona una nueva descripción de los neotipos de A. vernalis y A. robustus recopilados en sus localidades tipo en Rusia (estanque de Orlov, Peterhof) y Noruega (una corriente que sale de un lago en Oslo), con especial atención a su diferenciación morfológica respecto a A. americanus. Debido a la mezcla de estas especies prácticamente durante todo el siglo pasado y la rápida llegada del agresivo depredador planctónico A. americanus, todas las indicaciones anteriores de presencia de A. robustus deben verificarse y confirmarse. Se estudia la presencia de A. americanus en más de 200 localidades en la región de Valencia (España) y más de 30 ubicaciones en Armenia, Bélgica, Egipto, Finlandia, Francia, Kazajstán, Noruega, Rusia, Suecia y Túnez. En todos estos países, la especie invasora se encontró en grandes cantidades y como forma dominante, a menudo sustituyendo a las especies nativas de Acanthocyclops en las comunidades limnéticas. También se presenta una breve historia y posible explicación de la exitosa invasión de A. americanus en Eurasia.

Palabras clave: Acanthocyclops robustus; Acanthocyclops vernalis; redescripción de Acanthocyclops; taxonomía de ciclópidos; Acanthocyclops americanus; invasión biológica, distribución en Eurasia 


\section{INTRODUCTION}

Acanthocycops americanus (Marsh, 1892) a planktonic cyclopid first described from the Great Lakes in Northern America was found soon after by Lowndes $(1926,1928$ a) in Great Britain and later on in several other countries of the Old World (Dussart, 1967; Monchenko, 1961; Alekseev \& Kosova, 1976). It became the first documented invasive copepod species transported from the Americas to Europe. In the last century it was also found in limnetic communities throughout Eurasia. After Kiefer's (1976) mistaken designation of A. robustus (G. $\mathrm{O}$. Sars, 1863) as an older synonym of $A$. americanus, a lot of data indicating their differentiation has been accumulated (Alekseev et al., 2002, Lewis et al., 2004, Alekseev \& Monchenko, 2011, Miracle et al., 2013). Clearly visible ecological differences among planktonic $A$. americanus and littoral-benthic A. robustus in combination with limitation of classical morphological features used in taxonomy of this cyclopids caused it to become a challenge for several generations of European and American copepodologists.

To solve these taxonomical and ecological problems, representative populations from type localities of the respective taxa were analyzed morphologically and genetically using mitochondrial COI and 12S rRNA markers (Miracle et al., 2013). Molecular-genetic analysis revealed that A. robustus, A. americanus and $A$. vernalis are well-separated species. All studied European populations of $A$. americanus had small genetic distances to native American reference population obtained from terra typica. Consequently, all genetically studied $A$. americanus populations in Eurasia are recognized as a recent biological invasion as it was proposed by Lowndes (1926) (Miracle et al., 2013).

Soon after, a paper appeared on this robust$u s$-group, trying to reincarnate wrongly described A. einslei and A. trajani (Anufriieva et al., 2014). The authors of the paper totally ignored molecular-genetic evidence on the similarity/equivalence of $A$. einsli to A. robustus and $A$. trajani to $A$. americanus. They concentrate only on morphological differences quite common in different cyclopid population which is not enough nowadays when molecular-genetic tools have clearly corroborated that the morphologically different populations belong to the same species. Even excellent morphologists in XXI century cannot ignore results of molecular-genetic species validation that was confirmed for this Acanthocyclops robustus - vernalis complex recently (Błędzki \& Rybak, 2016). A good example could be found in Cyclops abyssorum group: many local populations of this group were described as separate species but in direct hybridization experiment of Einsle (1996) easily crossed with each other.

A. americanus dominates in many separated and even isolated waterbodies in Europe except in Arctic areas in Scandinavia and Russia. This species became a main summer planktonic invertebrate predator in large Ukrainian (Dnieper River) and Russian (Don River and Volga River) reservoirs. A. robustus should not be a dominating planktonic species due to preference to benthic (littoral) biotopes. All these water-reservoirs appeared during the $50-60 \mathrm{~s}$ of the last century after creation of cascade of hydropower electric stations. In the Rivers Volga, Dnieper and Dnestr no species of this genus was found in limnetic plankton. A. americanus was found in the Caspian Sea, Lake Sevan (Caucasus region), Lake Aral area, Lake Chany and northern reservoirs built at the Yenisey River (Western and Central Siberia). Recently, this species was found in North Africa, the Nile River delta and in Tunisian fresh waters (Victor Alekseev personal data, not published).

At the end of the XIX century, three species of the Acanthocyclops robustus group were described variously as: Acanthocyclops vernalis Fisher (1853) from the Saint Petersburg area (Russia); Acanthocyclops robustus Sars (1892) from the Oslo area (Norway); and Acanthocyclops americanus by Marsh (1892) from Wisconsin (USA).

$A$. americanus was redescribed on the basis of a neotype obtained from terra typica (Miracle et al., 2013). At the same time two other closely related sister-species, $A$. vernalis and $A$. robust$u s$, have not yet been redescribed following modern standards. That can create confusion 
between them and A. americanus or some other similar species of Acanthocyclops.

This paper provides a redescription of $A$. vernalis and $A$. robustus from the type localities with a special attention to differentiation from $A$. americanus. In addition, we provide new ecological features on $A$. americanus biology and current distribution based, first, on extensive European samplings and, second, on intensive and detailed samplings over a single Mediterranean area, Valencia region, as a case study. Both based on collection from authors and using the morphological differentiation detailed in the first part of the paper. Also, a possible brief history of biological invasion of $A$. americanus in Eurasia is discussed.

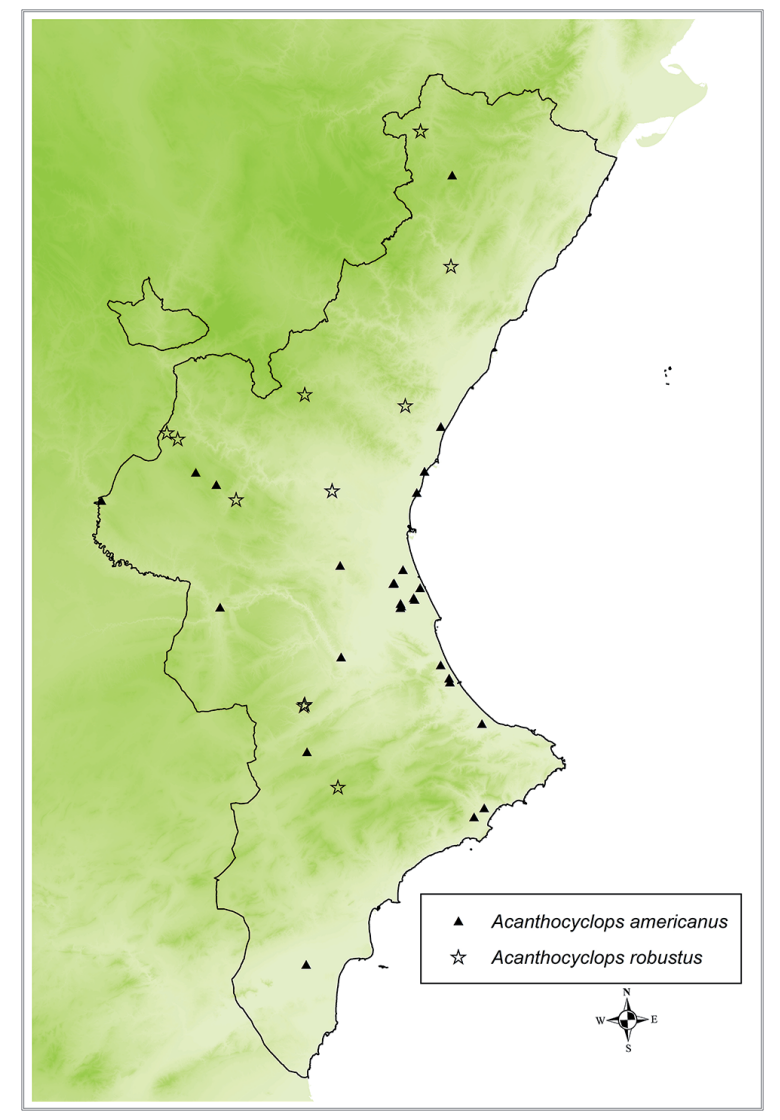

Figure 1. Sampling sites of Acanthocyclops species in Valencia region with indication of found species. Sitios de muestreo de las especies de Acanthocyclops en la región de Valencia con indicación de las especies encontradas.

\section{MATERIALS AND METHODS}

\section{1.- Morphological description of A. ameri- canus}

Morphological description of $A$. americanus had been done on material from terra typica, obtained from Prof. Stainly Dodson, Wisconsin USA (Miracle et al., 2013). Hereafter we have used neotype specimens of two morphologically close species which consist of: $10 \hat{\sigma}$ and 20 of $A$. vernalis selected from a sample taken in April 1998 in Orlov pond, Peterhof, St-Petersburg, the type locality for this species as it was described by $\mathrm{S}$. Fischer (1853); 8 $q$ and $2 \hat{\sigma}$ of $A$. robustus selected from a sample collected in a stream connected with Lake Maridalsvann, Oslo, Norway. A classical taxonomical method of external morphology examination has been used. Adult females and males before dissecting were photographed from dorsal side for a common view of animal with a 12-megapixel digital photo camera equipping Zeiss ImagerA1 microscope. Then specimens were dissected in a drop of glycerol on a microscope glass covered with a cover glass supported by droplets of plasticine on opposite corners to prevent damage of taxonomically important parts. Drawings were made at 400-1000x magnification with microscope equipped with Nomarski optics and a camera lucida, converted to ink, then digitized with scanner (resolution 1200 dpi) and used for mounting in drawings sheet. Each picture had a scale bar added. All slides obtained and used for study were catalogued and placed in the Federal Collection of Zoological Institute of RAS \#96-03-16 (Russia)

\section{Abbreviations used in description and drawings}

A1 - antennula; A2 - antenna; CR - caudal rami; CPT - cephalosome; GDS - genital double somite; Enp - endopodite; Exp - exopodite; P1-4 - swimming legs 1-4; P5-6 - rudimental legs; TH1-4 - free thoracic somite

\section{2.- Growth experiments}

Experiments and field observation were conducted in the Volga River delta laboratory. In a tempo- 
rary waterbody placed in Astrakhan State Nature Reserve regularly filled with Volga River water during Spring flooding, we filtered on a daily basis 100 liters with a 10 liter can via an Apstein zooplankton net (mesh size $70 \mu \mathrm{m}$ ) to observe the reactivation of copepod dormant stages present in sediment and population dynamics in several Acanthocyclops species coexisting together in the same pool. Species identification was done for females, males and diapausing copepodite stages 4-5 to the last stage. Special taxonomic keys were used for identification (Alekseev, 2000).

For growth experiments, 5-7 female of Acanthocyclops americanus and $A$. vernalis with egg sacs were picked up from the pool and incubated in lab until nauplii hatching out. Females were immediately killed and identified to subspecies level. Offspring was used in two types of experiments.

1. In lab conditions 30-50 nauplii of two Acanthocyclops species (A. americanus and $A$. vernalis as a control) were grown separately (one individual per experimental vial) and measured daily under microscope with ocular micrometer (resolution $7 \mu \mathrm{m}$ ). Each nauplius was placed in $20 \mathrm{ml}$ vial and at copepodite stages they were transferred to $100 \mathrm{ml}$ vials. Water change and organism measurements were done daily at the same time for each animal. Food for nauplii (protists and algae) and for copepodites and adult (crustaceans freshly killed by heating) was replenished after measurements once a day, temperature in lab was checked every 8 hours. Development time for each stage was first converted to $20^{\circ} \mathrm{C}$ and then estimated as an average $\%$ from female development time. Metabolic rate and productivity were calculated after Edmondson \& Winberg (1972) and also converted to $20^{\circ} \mathrm{C}$ following Crog's evacuation.

2. At least 30 individuals of both species (control groups) were placed in glass tubes covered on both sides with a double mesh membrane and reared directly in pool under natural conditions. Organisms were checked, counted and measured several times until maturation and became reference groups for laboratory grown ones.

Female fecundity was evaluated in about one hundred females randomly collected during the time of the species presence in zooplankton of the temporary waterbody. Embryonic development time was estimated in lab under controlled temperature. Observation for egg hatching time was carried out with a frequency of about one hour.

\section{3.- Distributions: sites and sampling methods}

\section{1.- Sampling methods and sites in Valencia region, Spain}

First references to the presence of Acanthocyclops in Valencia came in the 70s with the study of Albufera lagoon (Blanco, 1976) although unfortunately no specimens are available. Under the supervision of one of us (Dr. Miracle) several studies focused specifically on zooplankton in this coastal lagoon surrounding marshlands and other neighbouring coastal wetlands began in 1982 and have continued, until today (Oltra, 1993; Oltra \& Miracle, 1984; Alfonso \& Miracle, 1990; Alfonso, 1996; Miracle \& Sahuquillo 2002, Moss et al., 2003). The crustacean communities in inland ponds were studied during 2006 and 2007 in extensive surveys to cover the different eco-regions of the Comunitat Valenciana (Sahuquillo \& Miracle, 2013). Overall, we sampled 140 ponds (86 rain-fed ponds, 24 stream- or surface water-fed ponds and 30 spring- or groundwater-fed ponds) (Fig. 1). In all cases, to obtain the fullest possible representation of the planktonic and littoral microcrustacean communities in each site, we took semi-quantitative net samples from different mesohabitats (open waters of the central area, the vegetated littoral and very shallow shores). Littoral and plant-associated microinvertebrates were sampled by sweeping a $90 \mu \mathrm{m}$ hand-net through the vegetated areas and the shallow shores. From open waters, we took samples with $45 \mu \mathrm{m}$ towing nets. All the material collected was fixed in $4 \%$ formaldehyde and, additionally, some samples were preserved in alcohol for further molecular analyses, when needed.

\section{2.- Sampling methods and sites outside Spain}

Sites outside Spain where A. americanus was found and collected by one of us (V. A.), included 12 countries (Fig. 2). In deep lakes and water reservoirs, for sampling a tow net with open hole 


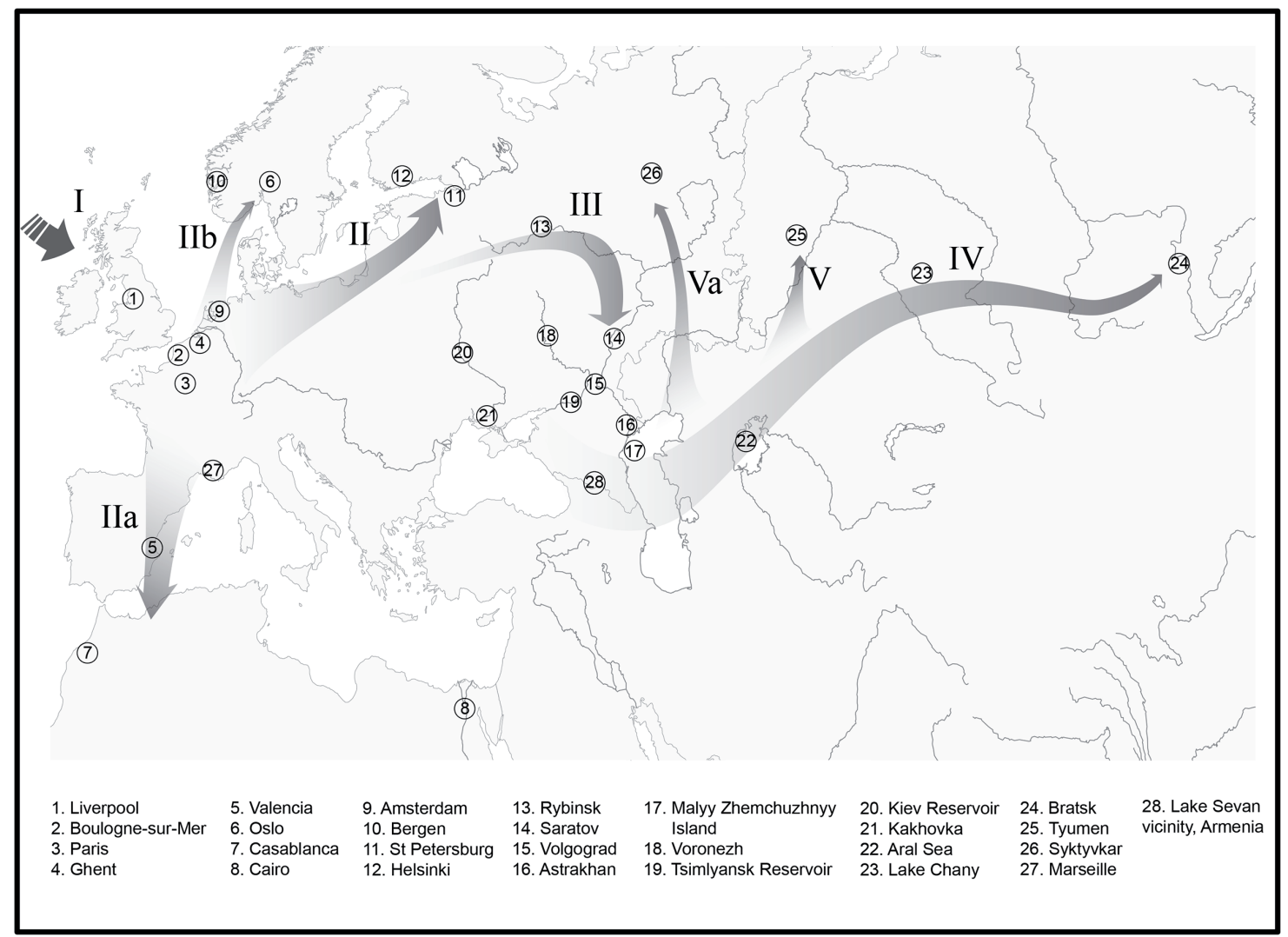

Figure 2. Sampling sites of Acanthocyclops americanus found in Eurasia. Numbers indicate the name of the places (see additional information in the Materials and Methods chapter). Arrows indicate the major seasonal aquatic bird migrations. Lugares de muestreo de Acanthocyclops americanus en Eurasia. Los números indican el nombre de los lugares (ver información adicional en el capitulo de Material y Métodos). Las flechas indican las principales rutas estacionales de migración de las aves acuáticas.

$25 \mathrm{~cm}$ diameter and mesh size $100 \mu \mathrm{m}$ was moved from bottom to surface in the central or the deepest parts of lake. In other shallow places, including 3 type localities in Norway, Russia and USA, 50-100 1 water with 101 can via a handle net (mesh size $100 \mu \mathrm{m})$ were filtered. Two types of samples were usually collected: formalin conserved for morphological studies and strong alcohol conserved for molecular-genetic and/or morphological studies.

Armenia: 1 shallow lake-let near Lake Sevan, the Caucasus Mountains; Belgium: 3 sites in Ghent and its vicinity; Egypt: 2 sites in Chair vicinity; Finland: 3 sites in Helsinki vicinity; France: 3 sites in Paris, 2 sites in Wimeraux, 3 sites in Camarg, Marseille vicinity; Germany: 3 sites in Plön vicinity; Kazakhstan: 1 site in Aral vicinity; Norway: 2 sites in Oslo vicinity; Russia: more than 20 sites all over the country from St Petersburg in the West to Irkutsk in the East and from Salekhard in the North to Caspian Sea in the South; Sweden: 2 sites in Stockholm vicinity; Tunisia: 2 sites in Hammamet and Tunis; Ukraine: 3 sites in Western, Southern and Eastern parts of the country.

\section{RESULTS AND DISCUSSION}

In many localities these three species were found together and in the same place. In large lakes and water reservoirs they maintained different niches as American invasive species is a typical planktonic form while $A$. vernalis and $A$. robustus inhabit littoral areas. Sometimes, as in shallow water bodies like temporary pools in the Volga 

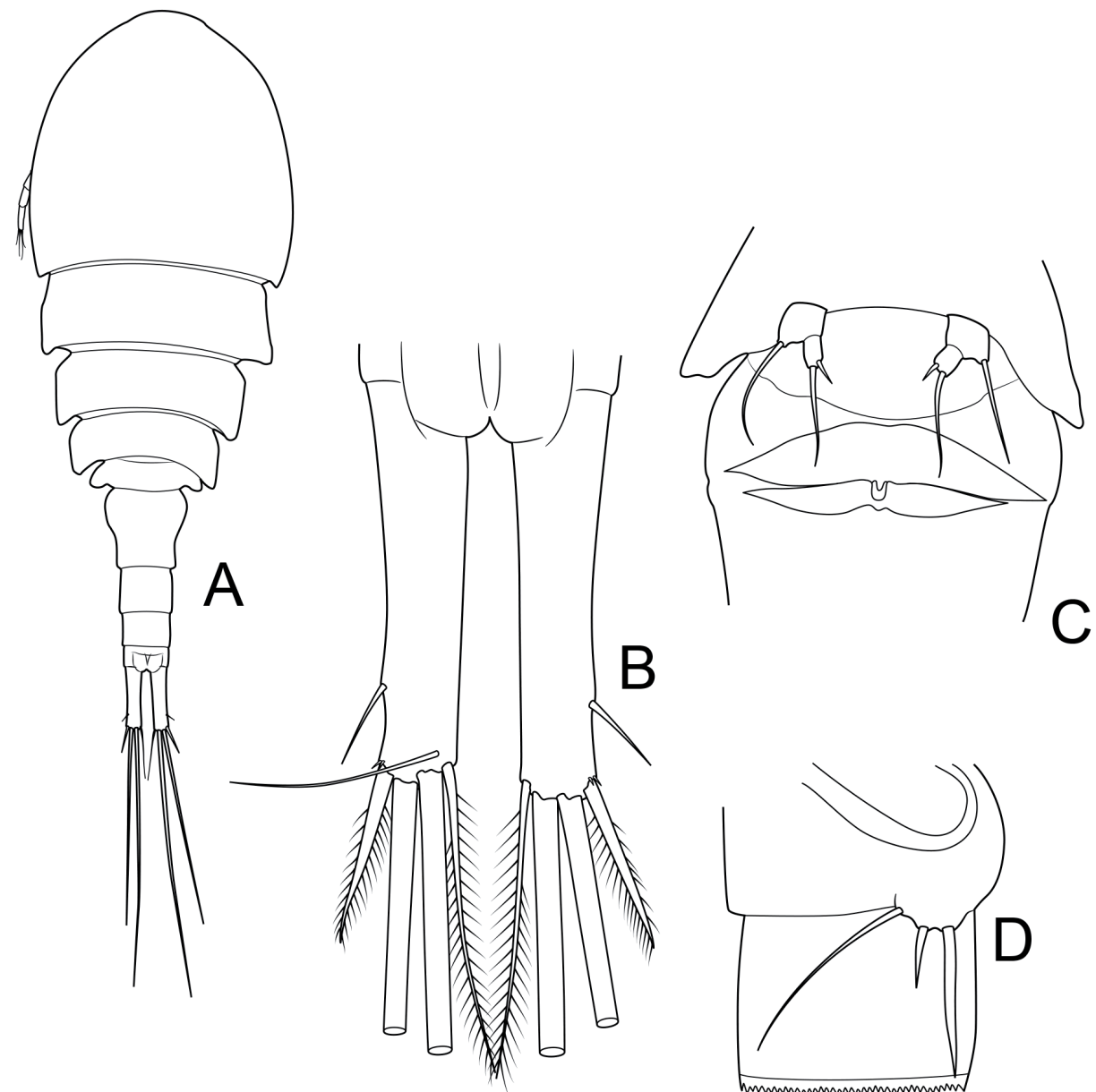

B
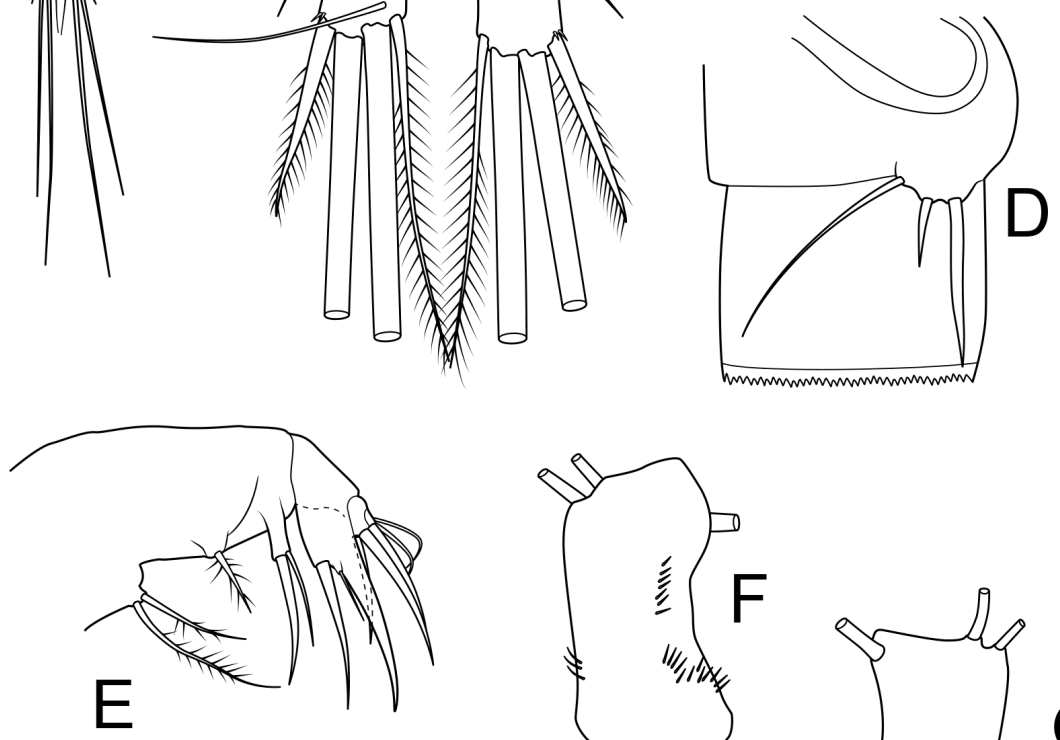

$\underline{\mathrm{C}, \mathrm{E}}$
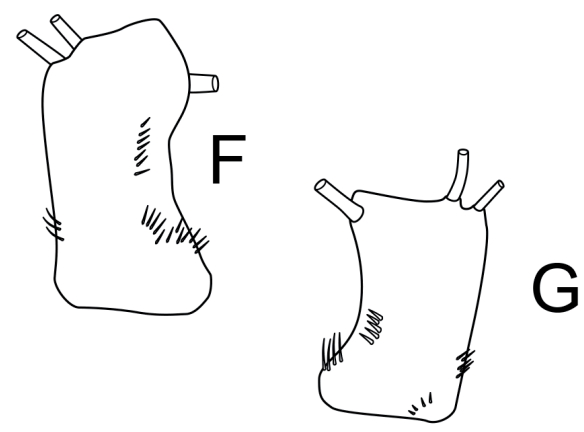

B, D

F, G

Figure 3. Acanthocyclops robustus, holotype of female (A, B, C, E, F, G) and paratype of male (D). Acanthocyclops robustus, holotipo de hembra (A, B, C, E, F, G) y paratipo de macho (D).

$A$ - habitus, dorsal; $B$ - caudal rami, dorsal; $C$ - genital segment, ventral; $D$ - P6 §; E - maxilla; F - antennal basipodite, frontal; $G$ antennal basipodite, caudal.

Scale bars: $A-220 \mu m ; B, C, D-50 \mu m ; E-20 \mu m ; F, G-40 \mu m$.

Original, V.A. 
River delta, they can be found in a sample collected by a handle net among waterplants. Actually, that became one of the reasons why F. Kiefer recognized $A$. americanus as a junior synonym of A. robustus after collecting a reference sample in the type waterbody near Oslo (Alekseev et al., 2002). The species being very close to each other show also high variability in classical morphological features.

To avoid the mixing up of these closely related species, hereafter we present descriptions for the three species of the robustus-group.

\section{Morphological peculiarities in the ameri- canus-vernalis-robustus group \\ Redescription of Acanthocyclops robustus (G.O. Sars, 1863)}

(Fig. 3, Fig. 4)

Cyclops robustus Sars, 1863

Acanthocyclops (Acanthocyclops) robustus, Dussart, 1969

Acanthocyclops (s. str.) vernalis f. robusta, Monchenko, 1974

Acanthocyclops vernalis robustus, Rylov, 1948 Acanthocyclops einslei: Mirabdullayev and Defaye, 2004; Vezhnovets, 2005; Dussart and Defaye, 2006; Rybak and Błędzki, 2010; Blaha, 2010

Acanthocyclops robustus: Kiefer, 1978; Einsle, 1993, 1996; Alekseev, 1995; Mirabdullayev and Defaye, 2004; Dussart and Defaye, 2006; Rybak and Błędzki, 2010, Miracle et al., 2013.

\section{Justification of neotype}

Victor Alekseev explored Zoological collections in several locations connected with Sars' work. In Oslo, Lund and Bergen no samples or slides that could be attributed to A. robustus were found. Our conclusion is that type material of Sars related to this species does not exist. Lake Maridalsvann is a large waterbody to the north of Oslo practically in the same state. Victor Alekseev visited it in June 2010 and sampled zooplankton in the lake and littoral zone plankton and meiobenthos in the lake and related with its waterbodies: bogs, small rivers coming into the lake. Regarding the plankton in the lake, only Acanthocyclops americanus was found in large densities. In littoral areas few members of other Acanthocyclops species which could be attributed to A. robustus were collected. Finally, in an unnamed stream coming into the lake, only one group of individuals was collected which could be identified as $A$. robustus males, females or copepodite later stages, dark in color, and they clearly different from planktonic form of Acanthocyclops from the lake. We used these individuals both for molecular-genetic and morphological studies. The neotype and type group of $A$. robustus were selected from this sample and are described hereafter.

Material examined. The neotype female and paratype male dissected and mounted in glycerol surrounded with Canadian balsam on slides N56736a and N56736b and deposited into the type collection of Zoological Institute of the Russian Academy of Sciences, St. Petersburg, Russia.

\section{Female description \\ (see Fig. 3, Fig. 4)}

Body robust, slightly flattened dorso-ventrally, dark-brown in color. Full body length without caudal setae $1300 \mu \mathrm{m}$. Cephalosome as long as wide, with maximum width close to its middle. Lateral angles 5th thoracic segment with winged outgrowths, directed laterally. Genital double-somite about as long as wide, round-shaped, receptaculum seminis as in figure 3. Anal segment with row of small dense spinules, proctodeum with single row of setules on both sides. Caudal rami parallel without hairs on inner or outer margins, 5 times as long as wide. Length proportions of distal setae, beginning from outer terminal seta: 1.0/6.7/9.2/1.7. Inner terminal seta shorter than ramus length. Dorsal seta about 1.2 times as long as outer seta and lateral seta slightly longer than ramus width.

Antennule of 17 segments, not reaching distal margin of cephalothorax. Setation of antennulary segments (aesthetascs in Roman numbers) beginning from first: $8 / 4 / 2 / 6 / 3+\mathrm{I} / 1 / 2 / 1 / 1 / 0 / 1+\mathrm{I} / 2 / 0 / 1 /$ $2 / 2+\mathrm{I} / 7+\mathrm{I}$. Antenna composed of 1 -segmented basipodite bearing exopodite represented by a long seta and the two short setae on opposite side, and a 3-segmented endopodite. Basipodite A2 ornamentation as in figures $3 \mathrm{~F}$ and $\mathrm{G}$. Three 


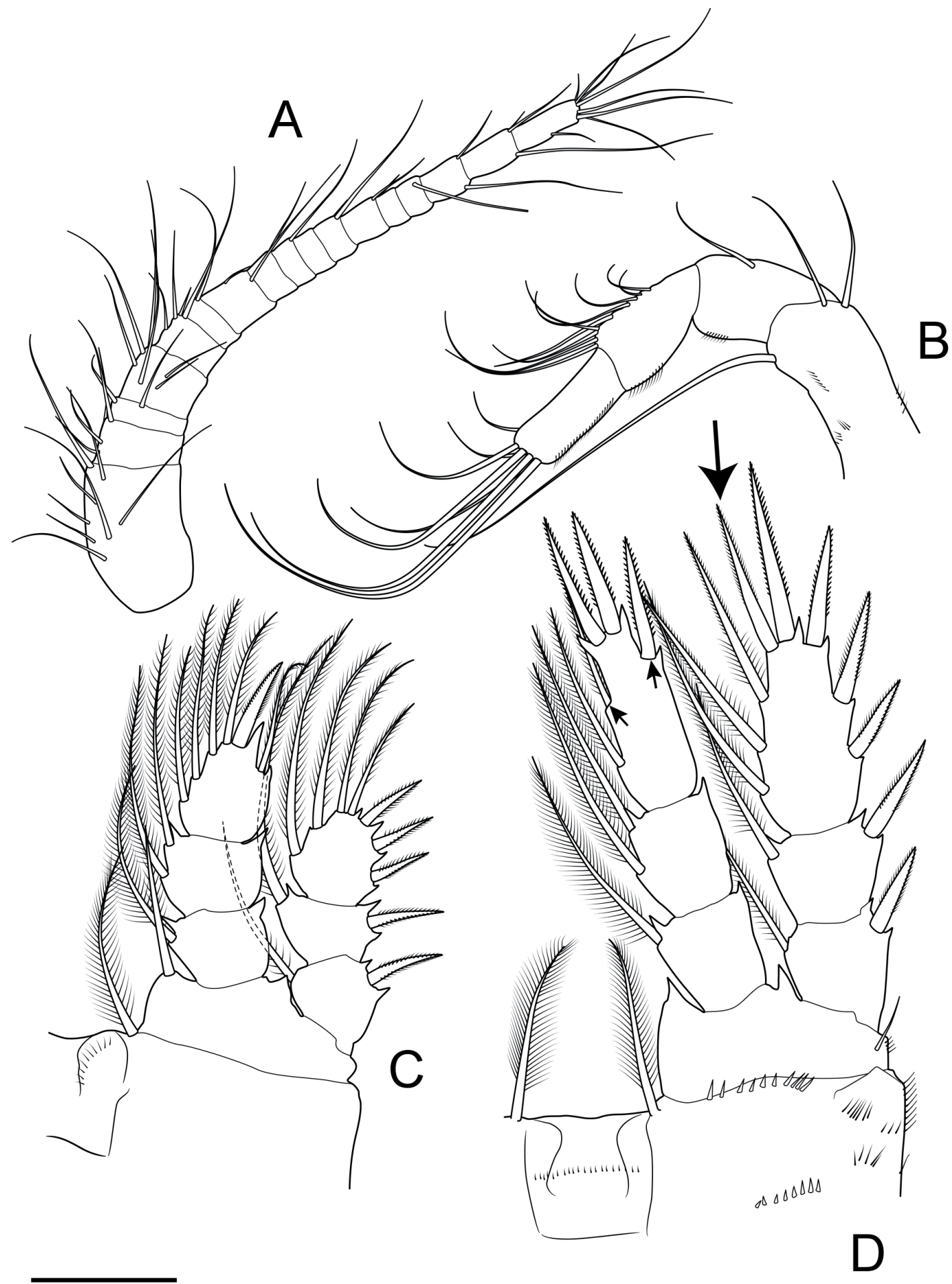

Figure 4. Acanthocyclops robustus, female holotype (A-D). Acanthocyclops robustus, holotipo de hembra (A-D). $A$ - antennule; $B$ - antenna; $C$ - P1; D - P4.

Scale bars: $A-200 \mu m ; B-50 \mu m ; C, D-100 \mu m$.

Original, V.A. 
following segments (endopodite) bearing subsequently: one, nine and seven setae.

Gnathobase of mandible with six strong teeth, rudiment of endopodal segment with 2 long and 1 short seta 1. Maxillula with 3 strong and 3 small teeth, 2 strong setae; maxillulary palp with 7 setae, different in length. Maxilla of 5 segments, praecoxa with 2 strong setae in its middle part; coxa with strong seta in middle and endite bearing 2 claw-like setae; basal endite with 2 very strong claw-like spines, both with row of spinules and small seta near place of fusion of rudimentary endopod. Endopodite 1 with 3 clawlike setae and endopodite 2 bearing distally 2 long setae. Maxilliped of 4 segments, praecoxa + coxa with 2 strong setae in middle part and small setae at their distal end; basis with 2 setae of different length and 3 groups of strong spinules near insertion of setae; first segment of endopodite with strong spine and rudimentary endopod, bearing strong spine and 2 hairless setae.

P1-4 with three-segmented rami. Distal segments of exopodite of legs $1 / 2 / 3 / 4$ with 3/4/4/4 spines, respectively. Distal segments of endopodite of legs 1-2 with 1 spine and 5 setae. P4 Enp3 about 2 times as long as wide and inner apical spine 1.13 times longer than outer spine. Lateral outer seta of this segment transformed in strong spine inserted not at same distance from end of segment as inner lateral seta (see Fig. 4D, small arrows). Setae of P4 Exp3 with very short hairs in distal part and long hairs in proximal part (see Fig. 4D, large arrow). P1-3 intercoxal plates with hills and without hairs on its free edge. P4 intercoxal plate with small hills and a row of short denticules in middle part. $\mathrm{P} 4$ coxopodite with two rows of spinules near distal and proximal margins and two groups of longer and thinner spinules near lateral margin. Rudimentary P5 two-segmented, basipodite with long outer seta. Distal segment with long apical seta and short inner spine; inner spine slightly more than half of segment length and exceeds segment width.

\section{Male description}

(see Fig. 3D and Fig. 7C)

Body length without caudal setae $925 \mu \mathrm{m}$. Cephalosome 1.2 times as long as wide, with maximal width close to end of its length. Caudal rami 3.8 times as long as wide, slender inner seta about twice length of outer spine-like seta. Lateral seta placed without spinules in its base. Dorsal seta placed near inner seta insertion, about as long as outer seta. Antennule 12-segmented. Setation of antennulary segments (aesthetascs in Roman numbers) beginning from first: $7(\mathrm{III}) / 3 / 1 / 6(\mathrm{I}) / 1 / 1 /$ $1 / 4(\mathrm{I}) / 0 / 1 / 0 / 7$. Antennary basopodite ornamentation as in female. Morphology of mouth appendages and Leg 1-3 basically as in female. Distal segment of P4 Enp about 2,5 times as long as wide, with inner apical spine shorter than segment and 1.15 times as long as outer apical spine. Insertion of lateral seta/spine in this segment as in female. Inner edge of basis of P4 with short hair-setae, coxa of P4 with strong spine. Caudal side of $\mathrm{P} 4$ coxa with same groups of spinules as in female but fewer in number. Intercoxal sclerite of P4 without hills and hair-setae on its free edge, but with short row of small spinules in middle. Rudimentary P5 two-segmented, with setae and spine of similar proportion to female. Rudimentary P6 with very short middle seta and very strong inner spine almost reaching length of outer seta (relative lengths $1.0 / 0.6 / 0.95$ ) clearly separating it from other species of this group.

\section{Redescription of Acanthocyclops vernalis (Fischer, 1853)}

(Fig. 5)

Cyclops vernalis Fischer, 1853

Cyclops parcus Herrick, 1882

Cyclops robustus (part.) Lilljeborg, 1901

Cyclops lucidulus G.O. Sars, 1863

Cyclops (Acanthocyclops) vernali Pesta, 1928; Kiefer, 1929; Yeatman, 1944

Acanthocyclops (Acanthocyclops) vernalis

Dussart, 1969

Acanthocyclops (s. str.) vernalis vernalis

Monchenko, 1974

Acanthocyclops (s. str.) vernalis f. robusta Monchenko, 1974

Acanthocyclops vernalis: Rylov, 1948; (part.) Margalef, 1953; Kiefer, 1978; Einsle, 1993; (part.) Einsle, 1996; Alekseev, 1998; Vezhnovets, 2005; Dussart and Defaye, 2006; Rybak and Błędzki, 2010 


\section{Justification of neotype}

Cyclops vernalis was described in the middle of XIX century by Fischer from a sample collected in Orlov pond, Peterhof town, St. Peterburg vicinity, Russia. Victor Alekseev checked collections of two Russian Zoological museums that existed at that time: collection of Zoological museum of Imperial Academy of Science in St. Petersburg and collection of Zoological museum of Moscow State University, Moscow. No samples attributed to Fischer were found nor any other materials related to copepods except description on paper. The type Orlov pond at Peterhof still exists and contains all five species described by Fischer including A. vernalis. This information let us conclude that type materials of Fischer except description on paper were lost and they do not exist now. Fortunately, the type waterbody, a small Orlov pond continued to exist in the same place all this time and no other Acanthocyclops species except $A$. vernalis were found

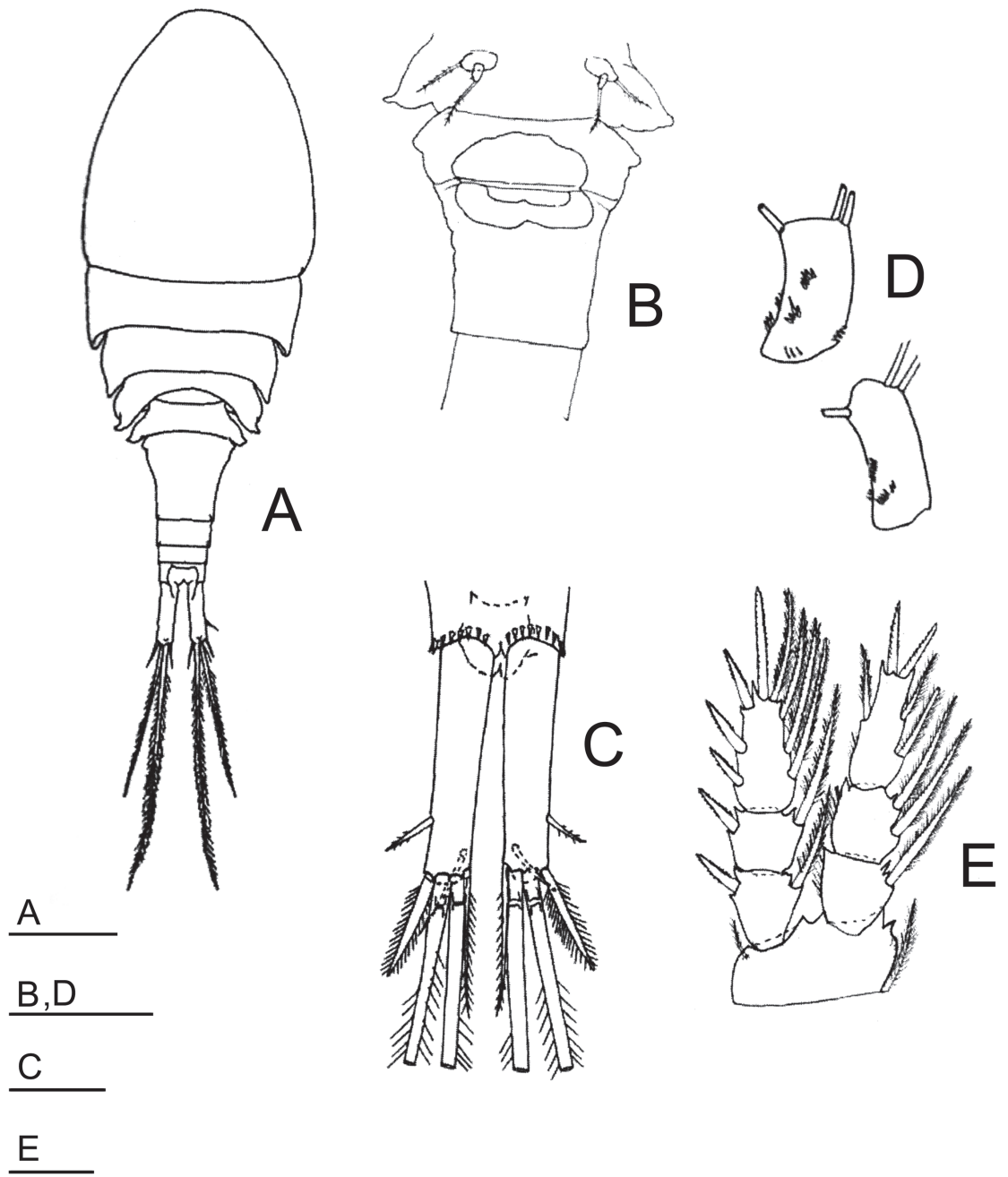

Figure 5. Acanthocyclops vernalis, holotype of female. Acanthocyclops vernalis, holotipo de hembra.

A - habitus, dorsal; $B$ - genital segment, ventral; $C$ - caudal rami, ventral; D - antennal basipodite, frontal; D1 - antennal basipodite, caudal; $E-P 4$.

Scale bars: $A-200 \mu m ; B-100 \mu m ; C-50 \mu m ; D, D 1-25 \mu m ; E-50 \mu m$.

Original, V.A. 
after its observation in April 1998 and all following visits up to now, approximately one-two times a year. That grants us the splendid possibility to establish the neotype of $A$. vernalis with a high probability from the same population that Fischer worked on.

Material examined. The neotype female and paratype male dissected and mounted in glycerol surrounded with Canadian balsam on slides N56736 and N56737 and deposited into the type collection of Zoological Institute of the Russian Academy of Sciences, St. Petersburg, Russia. The type series also includes two females and one male preserved in pure glycerol.

\section{Female description}

(see Fig. 5)

Body transparent, colorless. Full body length without caudal seta $1375 \mu \mathrm{m}$. Genital double-somite approximately as long as wide, with angular anterior part and sharpened lobes, receptaculum seminis with an anterior depression. Caudal rami parallel or slightly divergent, without hairs on inner margin, 5.5 times as long as wide. Inner seta 1.15 times longer than outer seta. Dorsal seta shorter than outer seta. Lateral setae not reaching ramus length. Length proportions of distal setae, beginning from outer terminal seta: $1 / 8 / 12 / 1.3$.

Antennule 17-segmented almost reaching distal margin of cephalosome. Setation of antennulary segments (aesthetascs in Roman numbers) beginning from first: $8 / 4 / 2 / 6 / 3+\mathrm{I} / 1 / 2 / 1 / 1 / 0 / 1+\mathrm{I} / 2$ / $0 / 1 / 2 / 2+\mathrm{I} / 7+\mathrm{I}$. Shortest setae of distal segment less than length of distal segment. Antenna composed of 1-segmented basipodite bearing exopodite represented by a long seta and the two short setae on opposite side, and a 3-segmented endopodite. Basipodite A2 ornamentation as in figure 5. Three following segments (endopodite) bearing subsequently: one, nine and seven setae.

Gnathobase of mandible with six teeth, rudiment of endopodial segment with 2 long setae and 1 short seta. Maxillula with three strong and three small teeth, two strong setae; maxillar palp with seven setae, different in length. Maxilla of five segments, praecoxa with two strong setae in its middle part; coxa with strong seta in the middle and an endite bearing two claw-like setae; basal endite with two very strong claw-like spines, both with a row of spinules and small setae near the place of fusion of the rudimentary endopod. Endopodite 1 with three clawlike setae and endopodite 2 bearing distally two long setae. Maxilliped of four segments, praecoxa + coxa with two strong setae in the middle part and small setae at their distal end; basis with two setae of different length and three groups of strong spinules near the insertion of the setae; first segment of endopod with strong spine and rudimentary endopod, bearing a strong spine and two hairless setae.

Swimming legs 1-4 with three-segmented rami. Distal segments of endopodite of Legs 1-2 with one spine and five setae. Distal segment of endopod Legs 3-4 elongated, with two strong spines at its end. In P4 Enp3 2.9 times as long as wide and outer apical spine slightly longer than inner one (1.2 times). Insertion of the lateral outer seta not at the same level from the end of the segment as the second lateral inner seta. Outer lateral seta of this segment not transformed in spine as it was in previous species, all setae homogeneously pinnated. Intercoxal plate of P4 with small hills and row of denticules in middle. P4 coxopodite with row of spinules along proximal margin, two groups of spinules at distal margin and groups of spinules near lateral margin. Rudimentary P5 two-segmented, basal segment with long outer seta. Distal segment with long apical seta and short inner spine less than half of segment length with few spinules at the base.

\section{Male description}

(see Fig. 5G)

Body length without furcal seta $915 \mu \mathrm{m}$. Cephalosome 1.3 times as long as wide, with maximal width close to end of its length. Caudal rami 4.3 times as long as wide, slender inner seta more than twice length of outer spine-like seta. Lateral seta placed without spinules in its base. Dorsal seta placed near inner seta insertion, about 1.2 times longer than outer seta. Antennule 12-segmented. Setation of antennular segments (aesthetascs in Roman numbers) beginning from first: 7(III)/3/1/6(I)/1/1/1/4(I)/0/1/0/7. Antennal baso- 

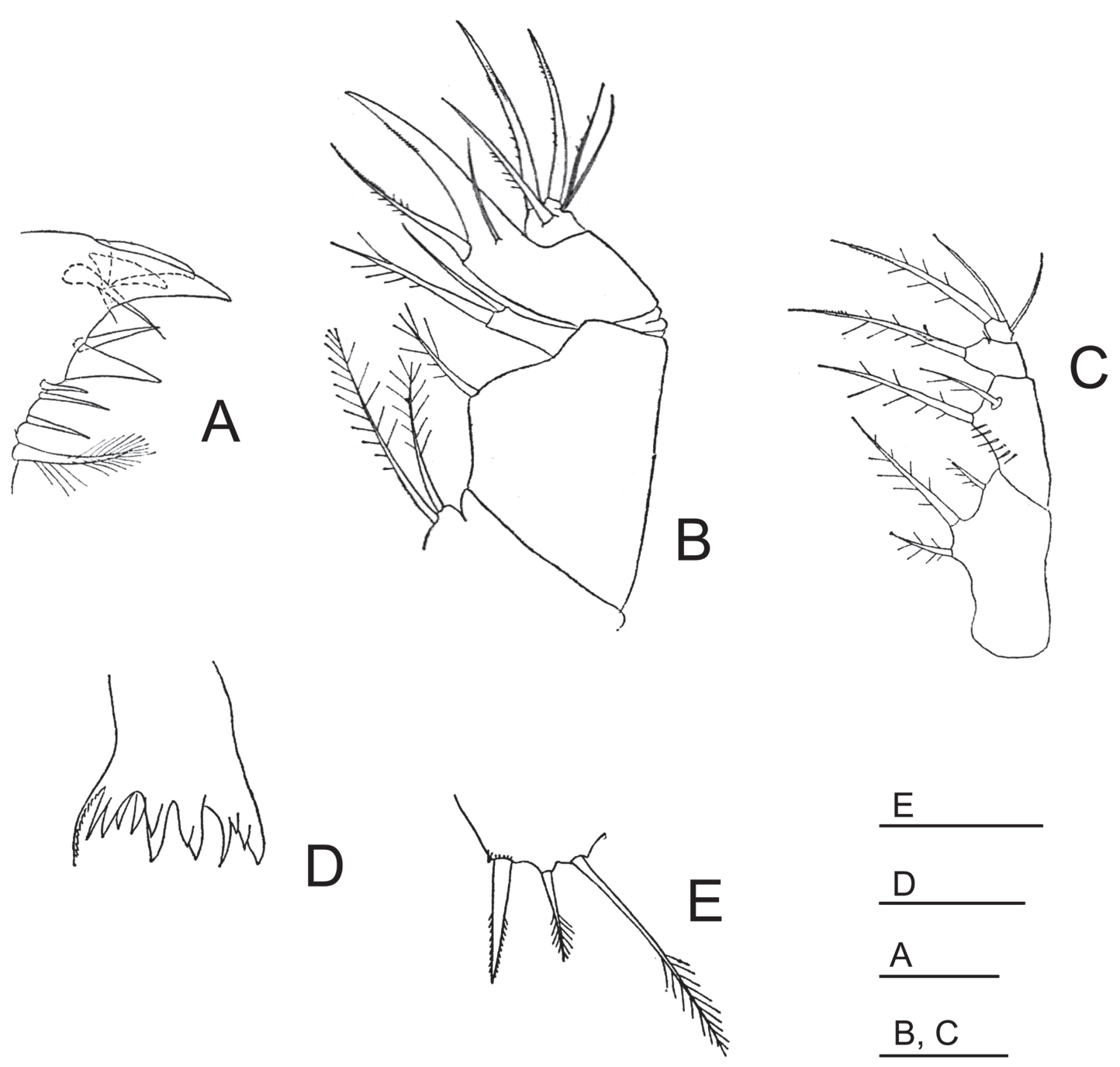

Figure 6. Acanthocyclops vernalis, female from the type seria (A-D), male (E). Acanthocyclops vernalis, hembra del tipo seria (A-D), macho (E).

A - gnathobase of maxilla; $B$ - maxilla; $C$ - maxiliped; $D$ - mandibula, distal part; $E$ - male, rudimentary leg 6. Scale bars: $A, D, E-30 \mu m ; B, C-50 \mu m$.

(After Monchenko, 1973 with changes)

podite ornamentation as in female. Morphology of mouth appendages and Leg 1-3 basically as in female. Distal segment of endopod Leg 4 about three times as long as wide, with inner apical spine about as long as the segment and 1.25 times as long as outer apical spine. Insertion of lateral seta in this segment as in female. Intercoxal sclerite Leg 4 without hills and hair-setae on its free edge, but with short row of small spinules in middle. Rudimentary Leg 5 two-segmented, with setae and spine of similar proportion to female. Rudimentary P6 with strong inner spine, middle seta shorter than spine and a very long outer seta (relative lengths 1.0/0.6/1.4).

Detailed redescription of $A$. americanus neotype from the type locality was done in our previous study (Miracle et al., 2013). Hereafter we decided to briefly remind the most important characters to show as the greatest possible difference in morphology among these three species. 
Acanthocyclops americanus (Marsh, 1892)

(Fig. 6)

Cyclops viridis americanus Marsh, 1892

Cyclops americanus Marsh, 1920

Acanthocyclops americanus f. spinosa Monchenko, 1961: Vezhnovets, 2005

Acanthocyclops robustus f. limnetica Petkovski, 1975

Acanthocyclops robustus: (part.) Kiefer 1976; Fryer, 1985; Dodson, 1994; Lescher-Moutoué, 1996; Einsle, 1996; Dussart and Defaye, 2006; Rybak and Błędzki, 2010

Acanthocyclops trajani Mirabdullayev and Defaye, 2002; Dussart and Defaye, 2006; Rybak and Błędzki, 2010; Blaha, 2010

Acanthocyclops (Acanthocyclops) americanus: Dussart, 1969

Acanthocyclops americanus: Rylov, 1948; Alek- seev, 1995; Vezhnovets, 2005; Alekseev et al., 2002

Female. Body colorless, length 1100-1600 $\mu \mathrm{m}$. Egg sacs with large number of transparent small size eggs. Cephalosome as narrow ellipsoid with maximal width close to middle. Fifth segment without long wings laterally. Genital double-somite round-shaped in lateral sides, 1.1-1.3 times as long as wide, with seminal receptacle with wide transparent zone in its frontal part (see Fig. 7). Caudal rami parallel or divergent, 4.5-6.5 times as long as wide. Innermost seta sub-equal to caudal rami length. Antenna composed of 1-segmented basipodite bearing exopodite represented by a long seta and the two short setae on opposite side, and a 3-segmented endopodite. Basipodite A2 ornamentation as in figure 6D,E. Mouth appendages

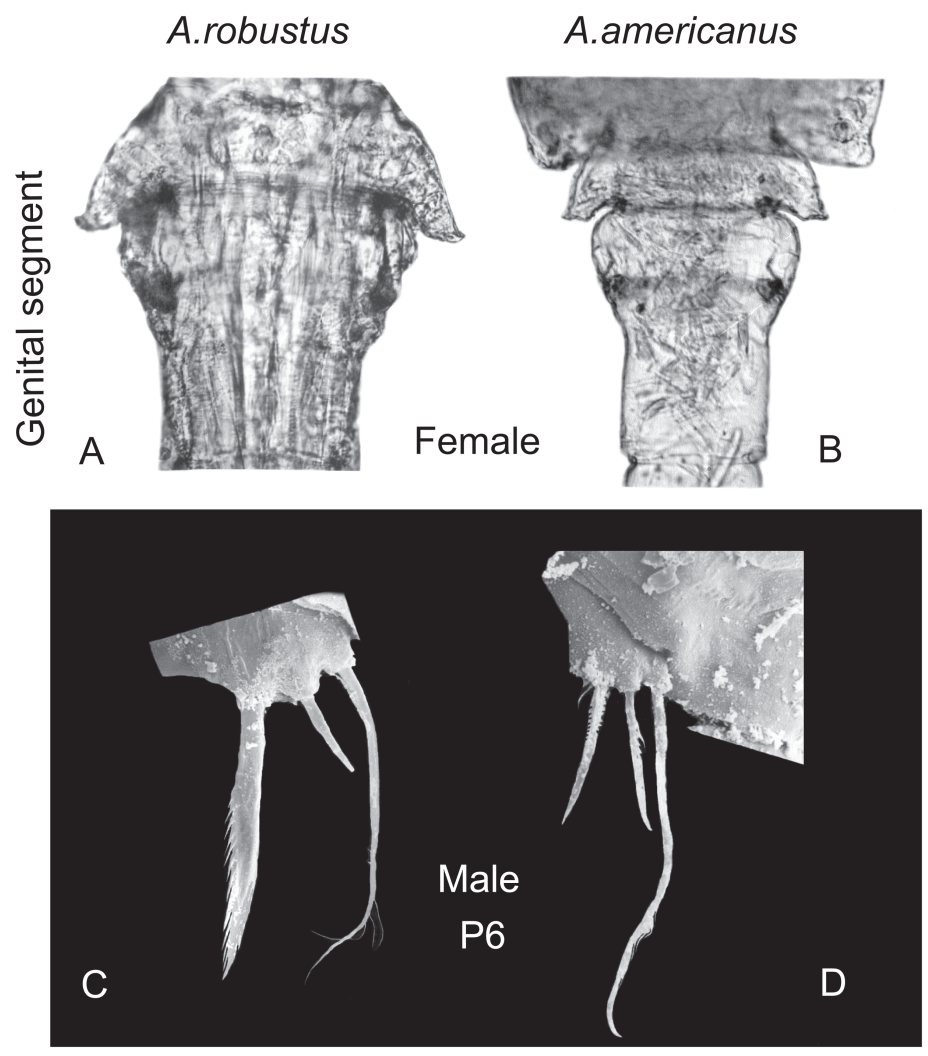

Figure 7. Comparative illustration showing the clear differences between female (A, B) and male (C, D) of Acanthocyclops robustus (A, C) and Acanthocyclops americanus (B, D). Ilustración comparativa que muestra las claras diferencias entre la hembra (A, B) y el macho $(C, D)$ de Acanthocyclops robustus $(A, C)$ y Acanthocyclops americanus $(B, D)$. 
as in other Acanthocyclops species.

P4 Enp3 2.6 times as long as wide; inner apical spine 1.1 times as long as outer spine and longer than segment itself. Insertion of the lateral outer seta approximately at the same level from the end of the segment as the second lateral inner seta. Intercoxal sclerite Leg 4 with small hills and row of small denticules in middle part. Coxa Leg 4 with four groups of denticles typical for several species of robustus-group. Distal segment exopod Leg 4 with distal seta longer than nearest distal spine. Rudimentary Leg 5 two-segmented, basal segment with long outer seta. Distal segment with long apical seta and short inner spine less than half of segment length.

Male. Body length without caudal seta 900-1100 $\mu \mathrm{m}$. Cephalosome 1.3 times as long as wide, with maximal width close to end of its length. Caudal rami 4-5 times as long as wide, slender inner seta more than twice length of outermost spine-like seta. Lateral seta placed without spinules in its base. Dorsal seta placed near innermost seta insertion, about 1.2 times longer than outer seta. Antennule 12-segmented.
Antennal basopodite ornamentation as in female. Distal segment of endopod Leg 4 about 2.5 times as long as wide, with inner apical spine about as long as the segment and 1.25 times as long as outer apical spine. Insertion of lateral seta/spine in this segment as in female. Rudimentary Leg 5 as in female. Rudimentary Leg 6 with inner weak spine, middle seta slightly shorter than spine and a very long outer seta 2 times longer than inner spine. (Fig. 7D).

\section{Comments on robustus-group differentiation}

Several morphological differences among the specimens from the type localities were found to assign the specimens unambiguously to the mentioned species of Acanthocyclops (Table 1).

Male differences in P6 construction among these species is also very clear and stable as observed in many populations inhabiting Eurasia (Alekseev \& Monchenko, 2011). In A. americanus male inner spine is weak and similar in size to middle seta when outer seta is very long and twice of inner spine length (Fig. 7D). In A. robus-

Table 1. The most important morphological features in female that separate invasive $A$. americanus from native sister species in Eurasia. Características morfológicas más importantes en hembras para separar la especie invasora A. americanus de las especies nativas de Eurasia.

\begin{tabular}{|c|c|c|c|}
\hline Characters/species & A. americanus & A. vernalis & A. robustus \\
\hline Body shape and color & Elongated, colorless & Robust, yellowish & Flattened, dark brown \\
\hline $\begin{array}{l}\text { Cephalosome } \\
\text { L/Wratio }\end{array}$ & $>1$ & 1 & 1 or $<1$ \\
\hline $\begin{array}{l}\text { Caudal rami shape } \\
\text { and } L / W \text { ratio }\end{array}$ & Divergent & Slightly divergent & Parallel \\
\hline $\begin{array}{l}\text { CR innermost/ outer } \\
\text { seta ratio }\end{array}$ & $>2$ & & 1.7 \\
\hline $\begin{array}{l}G D S \text { shape and } L / W \\
\text { ratio }\end{array}$ & round laterally $>1$ & Angular laterally $=1$ & round laterally $=1$ \\
\hline $\begin{array}{l}\text { P4 End3 distal seta } \\
\text { inserted places }\end{array}$ & $\begin{array}{l}\text { At the same distances } \\
\text { from end }\end{array}$ & $\begin{array}{l}\text { At different distances } \\
\text { from end }\end{array}$ & $\begin{array}{l}\text { At different distances } \\
\text { from end }\end{array}$ \\
\hline P4 End3 L/W ratio & More than 3 & $2.5-3$ & Less than 2.5 \\
\hline $\begin{array}{l}\text { P4 End3 inner distal } \\
\text { spine/L }\end{array}$ & More than 1 & About 1 & Less than 1 \\
\hline $\begin{array}{l}\text { P4 Exp3 distal seta / } \\
\text { distal spine }\end{array}$ & Seta $>$ spine & Subequal & Seta $<$ spine \\
\hline
\end{tabular}


tus this spine is strong and twice of middle seta length and subequal to outer length (Fig. 7C). In $A$. vernalis these appendages are of intermediate size and length (see Fig. 5). As mentioned above for females differences in P4 distal segment construction are similar to males and can be used for species separation purposes.

Microcharacters of the antennary basipodite that are so good taxonomic characters for species discrimination in some genus of cyclopoids such as Eucyclops or Mesocyclops, in our opinion, are too variable at population level in the genus Acanthocyclops to be used for species separation, at least in the robustus group (Lewis et al., 2004; Alekseev, 2015).

The critical point that lets us separate Eurasian species from the invasive American species became molecular genetic assessment conducted by Maria Rosa Miracle (Miracle et al., 2013). This study also improved species synonymy. Acanthocyclops americanus from Wisconsin (USA) and A. trajani described from Etàng de Noes (France) were morphologically and genetically alike as the same happening to $A$. robustus and $A$. einslei Mirabdullayev \& Defay, 2004 (Alekseev \& Monchenko, 2011; Miracle et al., 2013).

\section{Key for species identification in robust- us-group}

\section{Females}

1. P4 End3 inner distal seta and lateral seta inserted at the different levels from the segment end ...................... A. robustus (G.O. Sars, 1863)

[Native species within the Palearctic Region in Spain in rivers and springs (Maria Miracle, unpublished)]

- P4 End3 inner distal seta and lateral seta inserted at the same level from the segment end .. 2

2. P4 End3 apical inner spine shorter than apical outer spine A. vernalis (Fischer, 1853)

[Native species within the Palearctic Region but missing in Spain (probably)]

- P4 End3 apical inner spine equal or slightly longer than apical outer spine ....... A. americanus (Marsh, 1892)
Males

1. Rudimental P6 with weak inner spine; outer seta twice of its length ................... A. americanus (Marsh, 1892)

- This spine is strong; outer seta shorter ....... 2

2. Inner spine in P6 about as long as outer seta and twice of middle seta ..................... A. robustus (G. O. Sars, 1863)

- Inner spine significantly shorter .... A. vernalis (Fischer, 1853)

\section{Distribution of $A$. americanus and $A$. robustus at Valencia Region, eastern Spain}

Long time uncertainty of identification within the robustus-group caused by biological invasion of $A$. americanus in Eurasia resulted in wrong determination of species in most European countries (except Russia and Ukraine) and an absence of relevant information on these two species interaction as well as real areal occupied by $A$. americanus in XX century. Only recently, after molecular-genetic confirmation, regarding the invasive origin of $A$. americanus in Europe, this situation begins to turn better but still needs improving (Alekseev \& Monchenko, 2011; Miracle et al., 2013).

The morphological characters selected by us here in separating $A$. americanus from the native Eurasian species $A$. robustus were hereafter used to reveal modern distribution of $A$. americanus and $A$. robustus as well as the coexistence of these species in Valencia area, Spain. Thus, this becomes the first detailed study so far on the problem in Europe.

A database of the presence of these two Acanthocyclops species occurring in the Valencia region (eastern Iberian Peninsula) was compiled from several extensive sampling surveys, carried out by the authors under direction of Dr. Miracle through several different research projects from 2000 to 2017 . In total we collected data for more than 200 sampled sites. Sampled sites included: coastal lagoons (with low marine influence) and their surrounding temporary marshes along the Valencia coast; small ponds fed by rain (temporary ponds) or springs (permanent ponds) and sites associated with fluvial courses and major rivers. 
Table 2. Characteristics of wetlands where Acanthocyclops species have been found in Valencia region from a total of more than 200 sites studied. Características de los humedales en los que se encontraron especies de Acanthocyclops en la Comunitat Valenciana de un total de más de 200 lugares estudiados.

\begin{tabular}{lccc}
\hline Type of sites & $\begin{array}{c}\text { A. americanus } \\
\text { (Number of sites, } \%)\end{array}$ & $\begin{array}{c}\text { A. robustus } \\
\text { (Number of sites, } \%)\end{array}$ & $\begin{array}{c}\text { Conductivity } \\
(\mu \mathrm{S} / \mathrm{cm})\end{array}$ \\
\hline Coastal lagoons and marshes & 8 & 0 & $1800-3000$ \\
\hline River ponds & 5 & 4 & $538-1330$ \\
\hline Permanent ponds & 12 & 0 & $300-3050$ \\
\hline Temporary ponds & 2 & 10 & $93-585$ \\
\hline TOTAL & $27(66 \%)$ & $14(34 \%)$ & \\
\hline
\end{tabular}

Acanthocyclops species were found in 41 sites (Table 2). They were never found together in the same aquatic habitat and none of these species has been found in brackish waters. The distribution of both species highlights some of their differences in ecology. A. americanus was the most frequent species found in the current survey. In accordance with the data available in the studied area, $A$. robustus has not been found in any coastal lagoon, neither in permanent ponds, where was possibly substituted by the other species. It is important to note that the most permanent ponds sampled were also located in coastal areas. Ponds associated with rivers harbors both species approximately in equal proportions. The greatest part of sites with A. robustus are small temporary ponds isolated from water courses. From our sampling experience, these two species have been seen to occupy different habitats: A. robustus showing littoral preferences and $A$. americanus being more pelagic. Spatially (see Fig. 1) most sites with $A$. robust$u s$ are located in inland areas. This distribution possibly suggests that in the more connected coastal areas with greater anthropogenic influence, the invasive $A$. americanus species has displaced the native $A$. robustus species, while the latter is only preserved in small isolated ponds and in rivers in the most unpopulated inland area.

\section{Other countries}

In most sites outside Spain these two species were also found separately with two exceptions that became important for our study as we explain in the history of biological invasion of $A$. americanus and reasons why it was so successful.

The first exception - the type locality of $A$. robustus. In the type for $A$. robustus lake in Oslo (Norway) $A$. americanus was dominant in plankton when $A$. robustus was found in small numbers in a small shallow stream out-coming from the lake (Alekseev \& Monchenko, 2011). This sampling, done at the end of June 2010, confirms our previous inference that in the 60 s Kiefer also sampled $A$. robustus in the same lake and getting them together came to the mistaken conclusion on their identity (Alekseev et al., 2002). As a result he down-graded $A$. americanus as a synonym of a younger $A$. robustus. That mistake in effect blocked studies on the $A$. americanus invasion in Palearctic for more than 50 years. Hereafter we try to restore the main elements of the history of biological invasion of this species in Eurasia.

The second exception - seasonally temporary water bodies in the River Volga delta. The spring filling temporary water bodies in the Volga delta are highly productive and short time (1-3 months) existing habitat where species competition is low due to extremal environmental time limitation. This lets many species to co-exist effectively producing dormant stages highly resistant to desiccation and in the same site up to 200 copepod species including all three from the robustus group can be found living together (Alekseev, 1980). These special conditions are very suitable to study and compare life-cycle 
parameters in these morphologically close sister-species.

\section{A history of biological invasion of $A$. ameri- canus}

According to literature data in native habitat (the Americas) a planktonic cyclopid Acanthocyclops morphologically close to $A$. vernalis and $A$. robustus was described from the Great Lakes in North America (Marsh, 1892). Soon after, it was found in U. K. (Lowndes, 1928) possibly after oversea transport with ship ballast waters (Alekseev et al., 2002). In native habitat it is also known as a planktonic form, often dominating in eutrophic water bodies in Canada and Mexico (V. A. personal data).

In Spain and in France it was found in the middle of the last century (Dussart, 1967). As $A$. robustus f. pelagica it was registered in Hungary (Petkovski, 1975). Also it was presented in Kiefer's sample collected at south Norway (Oslo) (see Fig. 2) where it co-existed with $A$. robustus. This co-existence of $A$. americanus, dominating the plankton of the lake, and A. robustus, in low densities inhabiting small rivers connected with the lake, was confirmed by V. A. sampling at the same site in 2010.

It was a dominant species in Belgian creeks and in ponds of the Central City Park in Ghent, whereas $A$. robustus was only found in one location, a roadside ditch (Alekseev et al., 2003).

V. Rylov a very accurate taxonomist did not report any A. americanus in Russia before 1941 but included it in his key for cyclopids of USSR as a potential invader (Rylov, 1948). So we can suppose that $A$. americanus was not in Russia at that time as well as in European continental countries it was only found in the middle of last century.

Consequences after creation of large limnetic habitats (cascades of hydro-electric power stations with water reservoirs) on the Volga, Don, Dnepr and Dnestr Rivers

Acanthocyclops americanus was found for the first time in Russia in Rybynsk water reservoir (on the River Volga, started on 1941, and finished in 1947) in 1957 (Prof. A. Monakov personal com- munication to V.A.), then in Ukraine in Kievskoye reservoir (on the River Dnepr) and in Dnestr reservoir (Monchenko 1961, 1974). After creating a cascade for the hydro-power stations on the River Volga (1950-1960s) this species was found first in Saratov reservoir, then in Volgagrad reservoir (Vijushkova, 1962). In both reservoirs A. americanus was a dominative cyclopid in summer zooplankton (Vijushkova, 1962). In 1974 this species was also found in high densities in temporary waterbodies in the River Volga Delta (Alekseev \& Kosova, 1975). Few years later A. americanus was the only planktonic crustacean reported in the Caspian Sea (sea lagoons and rain pools on the island Zhemchuzhniy) (Chuykov, 1986). It was also present in Gulf of Finland (the Baltic Sea near St. Petersburg), 1981; in Armenia, near Lake Sevan (Caucasus), 1990; in Kazakstan near Lake Aral; and in lake Chanu (1985), in Western Siberia (a lake near the Tola River, Tumen, 1987); in Central Siberia, Bratsk water reservoir (the River Enisey), 1988. In 2015 it was found in a temporary rain pool near Syktyvkar (the northern Ural Mountains), and the same year in Hanko island near Helsinki (Finland). In 1996 and in 2003 it was found in Egypt (Nile river near Cairo). Recently it was also indicated in the Lena River delta (Abramova et al., 2017). Most of the lines connecting the sampling sites where A. americanus was found are similar to flyways of aquatic birds seasonal migrations.

\section{Biology of Acanthocyclops americanus, an invasive species in the Volga versus verna- lis-robustus native species}

Life cycle parameters that include growth and productivity rates, egg size and fecundity in $A$. americanus was compared to the same rates in $A$. vernalis obtained at the same temperature and food conditions (Alekseev, 1980). The invasive species had shorter maturation time (about $12 \%$ faster at $20^{\circ} \mathrm{C}$ ), higher metabolic level as well as feeding and productivity rates. If we compare time from egg laying until dormant stage (Copepodid 4), A. americanus show times shorter than those for A. vernalis. All these biological features along with higher fecundity are thought to be responsible for this invasive species to 
increase its competitive edge and substitute similar sized sister species in their niches.

\section{Acanthocyclops americanus seasonality in the River Volga delta}

This species was found in highest density not in permanent water bodies (rivers, lakes etc.) but in temporary ones (Alekseev \& Kosova, 1976). In spring river flooding pools that filled with water every year and are used by local and migrating fish for breeding and short time feeding, all these three species coexist together in more or less equal proportions (Alekseev, 1980). They appear at the very first stage of the spring water flooding.

There was some regularity in the appearance of these species at 4 th copepodid stages immerged in wet or just covered with thin films of water soil after 9-11 month dormancy in dry conditions.

$A$. vernalis appears first, then in one week comes $A$. robustus and finally when water temperature reaches $18-20{ }^{\circ} \mathrm{C} A$. americanus are found among reactivated formerly dormant copepods. In few days copepodites become adults (males in 1-3 days earlier) and immediately start reproducing. Before fish hatching the first generation of tiny nauplii appear and very soon they substitute adults consumed by young fish. Being numerous and small they can escape complete elimination by countless fish. Before the drying up of the water bodies, when fish are gone, populations of these species are ready for dormancy at copepodite $4^{\text {th }}$ stage thus they finish their life cycle having only one or two generations in a season. Even in these ephemeral water bodies we can observe differences in ecological demands between the invasive (Acanthocyclops americanus) and native (A. vernalis and $A$. robustus) species (Alekseev, 1980).

Appearance times for these species in the temporary water bodies were related to water temperature. At the very beginning of spring, when river water just arrived in this pool and temperature was about $14{ }^{\circ} \mathrm{C}, A$. vernalis copepodite stages were found emerging from the soil and in few days became adults and started breeding. At $16{ }^{\circ} \mathrm{C}$, copepodite $A$. robustus appeared and turned to maturation and breeding. Soon after, at $18-20{ }^{\circ} \mathrm{C}, A$. americanus and A. americanus spinosus had appeared. A. americanus seems to be more sensitive to temperature at the beginning of the life cycle and that may become a limiting factor in distribution of the species in the Arctic zone. Climate warming, on the other hand, must be a favorable factor to overcome this obstacle and to increase areal distribution northwards.

Small egg size and significantly higher female fecundity in invasive species could give them competitive advantages but only in high trophic conditions. If food is limited, especially in naupliar stages of development, species with large egg size will survive better. So the native species are deemed to be more effective in the early spring time and late fall season whereas invasive species should be more competitive in early summer time when small sized prey such as protist and rotifers are numerous.

Other studies on this species showed other advantages such as omnivorous diet (Sarma et al., 2019), rapid population growth rates, higher fecundity, effective predation on other cyclopid species and use of aquatic birds for dispersal in a similar way to Cladocerans (Ślusarczyk et al., 2019). Also the naupliar stages outcompete herbivorous cladocerans and thus possibly are dominant in zooplankton communities (Enríquez-García et al., 2013). We think that the fast and wider distribution of $A$. americanus became possible due to all mentioned above biological features.

\section{CONCLUSIONS}

1. The putative invasive species Acanthocyclops americanus can now be easily separated from the two native similarly sized species $A$. vernalis and $A$. robustus, both using morphological characters and molecular techniques. The most important taxonomical differences in females are related with P4 structure, in males with P6 armament.

2. Study on copepod diversity carried out in about 200 sites in Valencia region (Spain), revealed the presence of Acanthocyclops species in 41 sites: in $66 \%$ of the sites the genus is represented by the putative invasive species $A$. americanus and only in $34 \%$ sites $A$. robustus was the species found. These two species were never found together at the same place. 
3. Analysis of literature and our own sampling data on distribution of $A$. americanus in Eurasia lets us assemble a possible story of its invasion begun in early XX century from U.K.; today, the species is distributed throughout the Palearctic Region.

4. Experimental study of life cycle in $A$. americanus and the two native species showed a competitive advantage of the invasive planktonic species in limnetic communities in high trophic conditions.

5. Eutrophication, creation of large limnetic habitats (water reservoirs) and climate warming were favorable factors for the great success of its invasive and colonizing abilities to dominate in such a huge territory within a century.

6. There is a high risk that A. americanus in the near future may expand its area to the Arctic zone due to climate warming. As it was observed in many cases in shallow water bodies, $A$. americanus became the dominant planktonic species. Arctic water bodies are mainly small and shallow with limited number of invertebrate species. $A$. americanus as a very effective predator may dramatically change these vulnerable ecosystems. The last finding of $A$. americanus in the Arctic zone (Comi Republic and North Urals) recently sampled by E. Fefilova (personal communication) confirmed these preliminary conclusions.

\section{ACKNOWLEDGEMENTS}

The study was supported by the Spanish MICINN project CGL2009-12229. For this work, the Federal Collection N 96-03-16, Zoological Institute of the Russian Academy of Sciences (St. Petersburg, Russia) was used. The work was conducted in accordance with the national initiative of RAS (topics 65.4 and 65.5) and supported by Russian Government program on Biodiversity \#AAAA-A19-119020690091-0. The study on bioinvasion was supported by RFBR grant \#17-04-00027 and the collection of material on biodiversity in the area of the modern remains of the Tethys Sea was supported by RFBR grant \#20-04-00035. VA thanks the Astrakhan State Nature Reserve for help with carring out of experiments in the Volga River Delta. Olga Chaban's contribution is much appreciated for significant help with illustration and text composition. Also, the two anonymous referees deserve our acknowledgement for their helpful suggestions and corrections on the previous manuscript. This paper is "in memoriam" Dr. Maria Rosa Miracle.

\section{REFERENCES}

ABRAMOVA, E., VISHNYAKOVA, I., BOIKE, J., ABRAMOVA, A., SOLOVYEV, G. \& F. MARTYNOV. 2017. Structure of freshwater zooplankton communities from tundra waterbodies in the Lena River Delta, Russian Arctic, with a discussion on new records of glacial relict copepods. Polar Biology, 40: 1629-1643. DOI: 10.1007/s00300-017-2087-2 ALEKSEEV, V. R., E. FEFILOVA \& H. J. DUMONT. 2002. Some noteworthy free-living copepods from surface freshwater in Belgium. Belgian Journal of Zoology, 132: 133-139.

ALEKSEEV, V. R. \& A. A. KOSSOVA. 1976. Finding of Acanthocyclops americanus (Copepoda) in the delta of the Volga River. Zoologicheskii Zhurnal, 5511: 1726-1728.

ALEKSEEV, V. R. 1980. The growth, development and production of freshwater cyclopids in water bodies of the River Volga delta. $\mathrm{Ph}$. $\mathrm{D}$ in Aquatic Ecology ref.; Leningrad. Publishers of Inst. of the Lake and River Fishery: 1-24.

ALEKSEEV, V. R. 1986. Species dependent characters of naupliar behavior in freshwater Cyclopoids. In: Gagarin, V. G., editor. Behaviour of aquatic invertebrates. Material from the 4th All-Union Symposium, Borok 1983. Andropov (USSR): Academy of Sciences: 95-99. [In Russian.]

ALEKSEEV, V. R. 1998. Key to the freshwater Cyclopoidae of Russia and adjacent lands. Zoosyst Ross, 7: 23-43.

ALEKSEEV, V. R. 2000. Taxonomic analysis of species characters for copepodid instars 4 and 5 of the subfamily Eucyclopinae of European Russia. Hydrobiologia, 417: 57. pp 57-79. DOI: 10.1023/A:1003878616907

ALEKSEEV, V. R. 2015. Copepoda. In: Identification keys for fish and invertebrates of the Caspian Sea. SPb. KMK Scientific Press. pp. 
39-192.

ALEKSEEV, V. R. \& A. KOSSOVA. 1976. A finding of Acanthocyclops americanus in the delta of the Volga River. Zool Zhur. 53:1726-1728.

ALEKSEEV, V. R., E. FEFILOVA \& H. J. DUMONT. 2002. Some noteworthy free-living copepods from surface freshwater in Belgium. Belgian Journal of Zoology, 132:133-139.

ALEKSEEV, V. R. \& V. I. MONCHENKO. 2011. Morphological and molecular-genetic studies of copepod-sibling species. Aquatic invertebrate biodiversity in continental water-bodies. Spb. ZIN RAS. p.7-14 [In Russian, with English abstract].

ALFONSO, M. T. 1996. Estudio de las comunidades zooplanctónicas de los ecosistemas acuáticos del Parque Natural de la Albufera de Valencia. Ph. D. Thesis. University of Valencia, Spain.

ALFONSO, M. T. \& M. R. MIRACLE. 1990. Distribución espacial de las comunidades zooplanctónicas de la Albufera de Valencia. Scientia gerundensis, 16/2: 11-25.

ANUFRIIEVA, E., M. HOLYNSKA \& N. SHADRIN. 2014. Current invasions of asian cyclopid species (Copepoda: Cyclopidae) in Crimea, with taxonomical and zoogeographical remarks on the hypersaline and freshwater fauna. Annales zoologici, 64: 109-130. DOI: 10.3161/000345414X680636.

BLÁHA M, M. HULÁK, J. SLOUKOVÁ \& J. TESITEL. 2010. Molecular and morphological patterns across Acanthocyclops vernalis-robustus species complex (Copepoda Cyclopoida). Zoologica Scripta, 39:259-268.

BLANCO, C. 1976. Estudio de la contaminación de la Albufera de Valencia y de los efectos de dicha contaminación sobre la fauna y flora del lago. Ph. D. Thesis. University of Valencia, Spain.

BŁĘDZKI, L. \& J. RYBAK. 2016. Freshwater Crustacean Zooplankton of Europe: Cladocera \& Copepoda (Calanoida, Cyclopoida) Key to Species Identification. Springer, Basel, p.918. 10.1007/978-3-319-29871-9.

CHUYKOV, YU.S. 1986. Fauna planktonnykh bespozvonochnykh vodoyemov Severnogo
Prikaspiya i Kaspiya. - In.: Gidrobiologicheskiye issledovaniya estuariyev. L. Zool. in-t. pp. 58-74. [In Russian]

DAHMS H. U. \& C. H. FERNANDO. 1997. Redescription of Acanthocyclops brevispinosus (Herrick, 1884) from Ontario. Crustaceana, 70: 129-144.

DODSON, S. I. 1994. Morphological analysis of Wisconsin (USA) species of the Acanthocyclops vernalis group (Copepoda: Cyclopoida). Journal of Crustacean Biology, 14: 113-131.

DUSSART, B. H. 1967. Contribution à l'étude des copépodes d'Espagne. Vol. 42. Publicaciones del Instituto de Biologia Aplicada, 42: 87-105.

DUSSART, B. H. 1969. Les copépodes des eaux continentales d'Europe occidentale 2. Cyclopoïdes et biologie quantitative. Paris (France): Boubée.

DUSSART B. H. 1971. Acanthocyclops americanus en France. Bulletin du Muséum National d'Histoire Naturelle, 42: 725-729.

EDMONDSON, W. T., \& G. G. WINBERG [eds.]. 1971. A manual on methods for the assessment of secondary productivity in fresh waters. Ibp Handbook No. 17. F. A. Davis, Philadelphia (Blackwell Sci. Publ., Oxford and Edinburgh).

EINSLE, U. 1996. Copepoda: Cyclopoida. Genera Cyclops, Megacyclops, Acanthocyclops. Guides to the identification of the microinvertebrates of the continental waters of the world 10. The Hague (The Netherlands): SPB Academic.

ENRÍQUEZ-GARCÍA, C., S. NANDINI \& S. S. S. SARMA. 2013. Feeding behaviour of Acanthocyclops americanus (Marsh) (Copepoda: Cyclopoida). Journal of Natural History, 47 (5-12): 853-862.

FISHER, S. 1853. Beiträge zur Kenntnis der in der Umgebung von St Petersburg sich findenden Cyclopiden. Bulletin de la Société impériale des naturalistes de Moscou, 26: 74-100.

FRYER, G. 1985. An ecological validation of a taxonomic distinction: the ecology of Acanthocyclops vernalis and A. robustus. Zoological journal of the Linnean Society, 84: 165-180.

GURNEY, R. 1933. British freshwater Copepoda 
III. Cyclopoida. London: The Ray Society. KIEFER, F. 1976. Revision der robustus-vernalis Gruppe der Gattung Acanthocyclops Kiefer (Crustacea, Copepoda) (miteingehender Beurteilung des "Cyclops americanus" Marsh, 1892). Beitr Naturk Forsch SW-Dtschl. 35: 95-110.

KIEFER, F. 1978. Das zooplankton der binnengewässer 2. Vol. 26, Freilebende Copepoda. Stuttgart (Germany): E. Schweizerbart'sche.

LESCHER-MOUTOUÉ, F. 1996. Seasonal variation in size and morphology of Acanthocyclops robustus (Copepoda Cyclopoida). Journal of Plankton Research, 18: 907-922.

LEWIS, G., M. CHRISCINSKE, P. HUDSON \& L. LESKO. 2004. Cyclopoid copepods of the Laurentian Great Lakes. Acanthocyclops robustus. Ann Arbor (MI): Great Lakes Science Center; [cited 2004 Jun 12]. http:// www.glsc.usgs.gov/greatlakescopepods/ Detail.asp?GROUP=Cyclopoid\&SPECIES $=$ Acanthocyclops robustus

LOWNDES, A. G. 1926. On Cyclops americanus, Marsh. Ann. Mag. Nat. Hist. 17: 616-619.

LOWNDES, A. G. 1928a. Cyclops americanus Marsh. A discussion and description of its specific characteristics and its occurrence in Europe. Int. Revue Ges. Hydrobiol. 19: 12-20.

LOWNDES, A. G. 1928b. The result of breeding experiments and other observations on Cyclops vernalis Fisher and Cyclops robustus Sars. Int. Rev. Ges. Hydrobiol. 21: 171-188.

MARSH, C. D. 1892. On the Cyclopidae and Calanidae of central Wisconsin. Trans Wis. Acad. Sci. Arts Lett. 9: 189-224.

MIRABDULLAYEV, I. M. \& D. DEFAYE. 2002. On the taxonomy of the Acanthocyclops robustus species complex (Copepoda, Cyclopidae) 1. Acanthocyclops robustus (G.O. Sars, 1863) and Acanthocyclops trajani n. sp. Selevinia,1-4: 7-20.

MIRABDULLAYEV, I. M. \& D. DEFAYE. 2004. On the taxonomy of the Acanthocyclops robustus species complex (Copepoda, Cyclopidae): Acanthocyclops brevispinosus and A. einslei sp. n. Vestnik Zoologii, 38: 27-37.

MIRACLE, M. R. \& M. SAHUQUILLO. 2002. Changes of life-history traits and size in
Daphnia magna during a clear-water phase in a hypertrophic lagoon (Albufera of Valencia, Spain). Verhandlungen des Internationalen Verein Limnologie, 28: 1203 - 1208.

MIRACLE, M. R., V. ALEKSEEV, V. MONCHENKO, V. SENTANDREU \& E. VICENTE. 2013. Molecular-genetic-based contribution to the taxonomy of the Acanthocyclops robustus group. Journal of Natural History, 47: 863-888. DOI: 10.1080/00222933. 2012.744432.

MONCHENKO, V. I. 1961. On species independence of Acanthocyclops americanus (Marsh) and on its finding in the Soviet Union. Zoologicheskii zhurnal, 40: 13-19. [In Russian.]

MONCHENKO, V. I. 1974. Fauna of the Ukraine. Vol. 27, No. 3, Cyclopidae. Kiev (Ukraine): Naukova Dumka. [In Ukrainian.]

MOSS B., D. STEPHEN, C. ALVAREZ, E. BECARES, W. VAN DE BUND, S. E. COLLINGS, E. VAN DONK, E. DE EYTO et al., 2003. - The determination of ecological status in shallow lakes- a tested system (ECOFRAME) for implementation of the European Water Framework Directive. Aquatic Conserv: Marine and Freshwater Ecosystems, 13, 507-549

OLTRA, R. 1993. Estudio del zooplancton de dos lagunas litorales mediterráneas: el Estany de Cullera y la Albufera de Valencia. Ph. D. Thesis. University of Valencia, Spain..

OLTRA, R. \& M. R. MIRACLE. 1984. Comunidades zooplanctónicas de la Albufera de Valencia. Limnetica, 1: 51-61.

OLTRA, R. \& M. R. MIRACLE. 1992. Seasonal succession of zooplankton populations in the hypertrophic lagoon Albufera of Valencia (Spain). Archiv fur Hydrobiologie, 124: 187-204.

PETKOVSKI, T. K. 1975. Revision von Acanthocyclops-formen der vernalis-Gruppe aus Jugoslawien (Crustacea, Copepoda). Acta Mus Macadonici Sci. Nat., 14: 93-142.

RYLOV, W. M. 1948. Fauna of the USSR Crustacea 3. Cyclopoida of freshwater. Moscow (Russia): Akademii Nauk USSR- [In Russian.]

SAHUQUILLO, M. \& M. R. MIRACLE. 2013. The role of historic and climatic factors in the 
distribution of crustacean communities in Iberian Mediterranean ponds. Freshwater Biology, 58: 1251-1266.

SARMA, S. S. S., M. R. MIRACLE, S. NANDINI \& E. VICENTE. 2019. Predation by Acanthocyclops americanus (Copepoda: Cyclopoida) in the hypertrophic shallow waterbody, Lake Albufera (Spain): field and laboratory observations. Hydrobiologia, 829: 5-17. DOI: 10.1007/S10750-018-3546-7

SARS, G. O. 1863. Oversight af de indenlandske Ferskvandscopepoder. Forh. Vidensk Selsk. Christiania, 29: 212-262.
ŚLUSARCZYK M., B. PINEL-ALLOUL \& B. PIETRZAK. 2019. Mechanisms facilitating dispersal of dormant eggs in a planktonic crustacean. In: Alekseev V., Pinel-Alloul B. (eds.) 2019. Dormancy in aquatic invertebrates. Theory, human use and modelling. Springer. 137-162.

VIJUSHKOVA V. P. 1962. Raspredeleniye i dinamika chislennosti zooplanktona Volgogradskogo vodokhranilishcha $\mathrm{v}$ pervyye gody yego sushchestvovaniya (1959-1961 gg.) .Tr. Saratov, otd. GosNIORKH. - T.7. - pp. 29-50. [In Russian.] 